\title{
Ouvidoria, caminho para a civilidade e o diálogo
}

\author{
Ombudsmanship and listening, the way \\ to civility and dialogue
}

\author{
La defensoría, un camino hacia \\ la civilidad y el diálogo
}

Cristina Ayoub Riche ${ }^{1}$

Há vinte anos acontecia a queda do Muro de Berlim. Quantos muros e quantas muralhas, visíveis e invisíveis, teremos que destruir para construir pontes? Pontes que unem e permitem os passos libertos e livres, em busca de novas descobertas, revelações e inovações, para a construção de um mundo melhor e mais humano.

Construir pontes, tarefa hercúlea e primordial de ouvidorias públicas, que devem conhecer os anseios da sociedade, dar voz aos que não têm vez, aos invisíveis, promover o acesso à informação, como um dever do Estado e um direito do cidadão, com o intuito de transformar a cultura do segredo e da segregação na cultura da transparência e da democracia participativa.

Ouvidoria não é modismo! É um remédio constitucional que serve para prevenir, combater e tratar as patologias sociais. Sua existência em instituição pública pode ser a garantia para acabar com a apatia, com a abulia política e com a descrença na prestação adequada e eficiente dos serviços.

Ela apaga do dicionário cotidiano do servidor público a expressão "isso não é comigo" ou "vá se queixar com o outro" e, concomitantemente, dá à sociedade a oportunidade de conhecer, reconhecer e exigir a prestação desses serviços públicos que devem estar, permanentemente, à sua disposição. Sua função

1 Advogada, é professora e ouvidora da Universidade Federal do Rio de Janeiro (UFRJ). 
é pública: garantir o acesso à informação e, por meio deste, acesso a outros direitos, entre eles, educação, saúde e assistência social.

A proposta de uma ouvidoria pública, por trabalhar constantemente com a insatisfação humana e com o desconhecimento dos cidadãos sobre os seus direitos e deveres, é justamente a de transformar a cultura da reclamação em uma cultura de cooperação e de participação. Nessa cultura o bom senso, a ética, o respeito à diversidade e o diálogo têm prevalência nas relações entre as partes envolvidas. Deve ser um órgão de natureza mediadora, sem caráter deliberativo, executivo ou judicativo, no qual prevaleçam os princípios da equidade, da transparência e da autonomia da vontade. O intuito é, também, garantir os direitos do cidadão, com base nos princípios constitucionais que regem a administração pública.

O princípio da eficiência é a base constitucional de uma ouvidoria, conforme disposto na Constituição da República Federativa do Brasil, nossa "constituição cidadã”. Esta estabelece a necessidade de participação popular no acompanhamento da prestação de serviços públicos, o que viabiliza a efetiva concretização do controle social. Entretanto, a ouvidoria, conforme a concebemos, não tem qualquer ingerência nas decisões dos gestores, mesmo porque a ela não cabe decidir. Procura, sim, estabelecer um canal de comunicação que, continuamente, permita a oitiva e a interpretação adequada das demandas recebidas, sejam elas da comunidade interna da instituição ou da comunidade externa. Deve ser um espaço acolhedor, de compreensão, de valorização do ser humano, buscando construir pontes, abrindo novos horizontes, para a reflexão e para o diálogo.

E uma das principais razões de existir de uma ouvidoria deve repousar na possibilidade de transformar a sociedade, diminuindo o déficit de cidadania, cuidando para que o cidadão passe a ser o sujeito e não o objeto de sua história. Como recurso de governança, apoiado nos princípios da ética e da transparência, a ouvidoria serve não somente para proteger o cidadão e esclarecê-lo sobre direitos e deveres, mas também para o surgimento de uma demanda social: cidadãos passam a ser mais exigentes relativamente à qualidade dos serviços prestados, tendo como contrapartida a oportunidade de melhoria e aperfeiçoamento desses serviços.

As manifestações dos que acorrem à ouvidoria, independentemente de sua natureza, sempre se traduzem em sinais de alerta, desafios e momentos intensos de reflexões. Além disso, o respeito à diversidade, à opinião do outro, à necessidade do outro, é essencial para retirar o cidadão da condição de demandante/reclamante e alçá-lo à condição de consultor habilitado e competente da instituição. Portanto, ao mesmo tempo em que viabiliza o controle social, a democracia participativa, a ouvidoria é uma ferramenta de gestão.

É, exatamente, esse entendimento que nos permite atuar, pedagogicamente, 
para transformarmos a cultura da reclamação em uma cultura de participação e de cooperação. O que desejamos é garantir a consolidação da democracia, da soberania nacional, buscando contribuir para a construção de uma sociedade mais justa, mais solidária, mais igualitária, na qual a paz social e a defesa do bem comum sejam concretizadas.

Nós, ouvidores, devemos atuar para que os momentos difíceis e de conflitos daqueles que nos procuram se traduzam em possibilidade real de aperfeiçoamento institucional. Dessa forma, prevalecerá o diálogo, conciliando os projetos e valores pessoais do corpo social da instituição com a boa e consciente gestão, para superar os gargalos e, consequentemente, atender aos anseios da sociedade, na prestação de um serviço eficiente, de qualidade, de excelência.

O bom desempenho de uma ouvidoria pública é fundamental para viabilizar a inclusão social e a participação do cidadão, é essencial para que as vozes dos sujeitos, muitas vezes considerados invisíveis, se transformem em hino da civilidade, da liberdade, da esperança e da igualdade social. 